\title{
Forms of Energy Delivery during Cryo-cooled Radiofrequency Ablation for Optimization of the Ablation Result
}

\section{Variationen der Energieabgabe während kryo-gekühlter RF-Ablation zur Optimierung des Ablationsergebnisses}

Authors

Affiliations
R. Hoffmann ${ }^{1}$, J. Bustamante' ${ }^{1}$, C. Pitsaer ${ }^{2}$, M. Voigtländer ${ }^{2}$, M. D. Enderle ${ }^{2}$, C. D. Claussen ${ }^{1}$, S. Clasen ${ }^{1}$, H. Rempp ${ }^{1}$

Diagnostic and Interventional Radiology, University Hospital Tübingen

ERBE Elektromedizin GmbH, ERBE, Derendingen
Key words

- ablation procedures

- experimental study

- radiofrequency (RF) ablation

- technical aspects

received $\quad 3.1 .2014$

accepted 17.2.2014

Bibliography

Dol http://dx.doi.org/

10.1055/s-0034-1366232

Published online: 1.4 .2014

Fortschr Röntgenstr 2014; 186:

945-950 @ Georg Thieme

Verlag KG Stuttgart · New York .

ISSN 1438-9029

\section{Correspondence \\ Dr. Rüdiger Hoffmann}

Diagnostic and Interventional

Radiology, University Hospital

Tübingen

Hoppe-Seyler-Str. 3

72076 Tübingen

Germany

Tel.: ++49/7071/2986677

Fax: ++ 49/70 71/294638

ruediger.hoffmann@med.

uni-tuebingen.de

License terms

\section{Abstract}

$\nabla$

Purpose: Energy transfer from radiofrequency (RF) applicator to tissue is both precondition and limiting factor. The purpose of this ex vivo study was to examine the influence of form of energy delivery on ablation result during RF ablation with cryo-cooled applicators.

Materials and Methods: One hundred eight ablations were performed in ex vivo bovine liver under continuous energy delivery (A), pulsed energy delivery with reduced current during ablation pause (B) and impedance-dependent energy delivery. Maximum ablation time was 20 min. Early termination of ablation in case of loss of conductivity. Optimal ablation parameters were assessed. Short axis diameter of the ablation zone and ablation duration were determined. Ablation results under mode A, B and C were compared with analysis of variance and Tukey-Kramer HSD test. Influence of ablation duration on short axis diameter was evaluated with regression analysis.

Results: Significantly largest short axis diameter $(51.1 \mathrm{~mm} \pm \mathrm{SD} 2.3 ; \mathrm{p}=0.01)$ was reached with impedance-dependent energy delivery (pulsed: $46.1 \mathrm{~mm} \pm \mathrm{SD} 5.6$; continuous: $44.4 \mathrm{~mm} \pm$ SD 4.1). Significantly longest ablation duration $(1061.6 \mathrm{~s} \pm \mathrm{SD} 42.4 ; \mathrm{p}=0.01$ ) was reached with impedance-dependent energy delivery (pulsed: $815.7 \mathrm{~s} \pm 41.3$; continuous: $715.3 \mathrm{~s} \pm$ SD 82.2). Linear correlation between ablation duration and short axis diameter was calculated $(R=0.7)$.

Conclusion: Modification of energy delivery during RF ablation with cryo-cooled applicators improves energy transfer to tissue and enables larger ablation zones.
Key Points:

- Impedance-dependent energy delivery prevents early termination in kryo-based RF-ablation,

- Impedance-dependent energy delivery enables larger ablation zones than continuous energy delivery,

- Reduced current during ablation pause does not improve ablation results.

Citation Format:

- Hoffmann R, Bustamante J, Pitsaer C etal. Forms of Energy Delivery during Cryocooled Radiofrequency Ablation for Optimization of the Ablation Result. Fortschr Röntgenstr 2014; 186: 945-950

\section{Zusammenfassung \\ $\nabla$}

Ziel: Der Energietransfer von Radiofrequenzsonden (RF-Sonden) auf das Zielgewebe ist Voraussetzung und limitierender Faktor der RF-Ablation. Ziel dieser Ex-vivo-Studie ist die Untersuchung des Einflusses der Form der Energieabgabe auf das Ablationsergebnis während RF-Ablation mit kryogekühlten Sonden.

Material und Methoden: Insgesamt 108 Ablationen wurden unter kontinuierlicher Energieabgabe (A), gepulster Energieabgabe mit reduzierten Ablationsströmen während Ablationspausen (B) und impedanzabhängiger (C) Energieabgabe an ex vivo Rinderlebern durchgeführt. Die Ablationszeit betrug maximal $20 \mathrm{~min}$. Ggf. vorzeitiger Abbruch der Ablation bei Verlust der Gewebeleitfähigkeit. Optimale Ablationsparameter wurden ermittelt. Der Kurzachsendurchmesser der Ablationszone und die erreichte Ablationszeit wurden ermittelt. Der Vergleich der unter Ablationsmodi A, B und C erreichten Ergebnisse erfolgte mittels Varianzanalyse und Tukey-Kramer HSD-Test. Der Einfluss der Ablationszeit auf den Kurzachsendurchmesser wurde mit Regressionsanalyse untersucht. 
Ergebnisse: Der signifikant größte Kurzachsendurchmesser (51,1 mm \pm SD 2,3; p =0,01) wurde unter impedanzabhängiger Energieabgabe erreicht (gepulst: $46,1 \mathrm{~mm} \pm$ SD 5,6; kontinuierlich: $44,4 \mathrm{~mm} \pm \mathrm{SD} 4,1$ ). Die signifikant längste mittlere Ablationszeit $(1061,6 s \pm S D 42,4 ; p=0,01)$ wurde unter impedanzabhängiger Energieabgabe erreicht (gepulst: 815,7s $\pm 41,3$; kontinuierlich: 715,3 s \pm SD 82,2). Eine lineare Korrelation zwischen Ablationszeit und Kurzachsendurchmesser wurde ermittelt $(R=0,70)$.

Schlussfolgerung: Durch Modifikation der Energieabgabe während RF-Ablation mit kryogekühlten Sonden lassen sich die Energieübertragung auf das Gewebe verbessern und größere Ablationszonen erzielen.

\section{Introduction}

$\nabla$

Radiofrequency (RF) ablation is increasingly used to treat primary and inoperable secondary lesions of the liver [1 $3]$, and is additionally gaining significance in the treatment of malignancies in other organs [4-6]. The advantages of this treatment method include potential curative effects, lessened rate of complications, reduced loss of healthy tissue and short patient hospitalization time. Although the local recurrence rate in the case of small tumor size is quite encouraging, treatment of tumors greater than $3 \mathrm{~cm}$ in diameter is frequently associated with high local recurrence rates [7-10]. Tumors with greater diameters extend beyond the limits of clinically used ablation systems, since a sufficient safety margin in the area around the tumors must be obtained. In addition to repositioning applicators to achieve overlapping ablation zones, various other strategies are employed to enlarge the short axis diameter of the ablation zone (orthogonally to the axis of the applicator), including expandable, multipolar and cluster systems with several parallel applicators [11, 12]. Internal applicator cooling has additionally shown itself to be efficient, since it reduces tissue carbonization while minimizing loss of electrical conductivity of the tissue $[13,14]$. In addition to internal water cooling, $\mathrm{CO}_{2}$-based, gas-cooled cryo applicators with greater cooling capacity have been used [15]. It has been shown that such systems result in an optimal expansion of the ablation zone using the highest possible electrical output [16]. This was based on continuous energy delivery and cooling, whereas in water-cooled systems it has been demonstrated that pauses in energy delivery have a positive impact on the ablation zone [17, 18]. Using an ex vivo bovine liver model, this study investigates how a pulsed or impedance-dependent energy application affects the results of the ablation.

\section{Materials and Methods}

$\nabla$

\section{Ablation Probe and Generator}

The tests were performed using monopolar cryo-RF ablation probes (ERBE, Tübingen, Germany) with an active electrode length of $3 \mathrm{~cm}$ and a diameter of $1.8 \mathrm{~mm}$ ( $\bullet$ Fig. 1). Cooling used the Joule-Thompson principle [15]: compressed $\mathrm{CO}_{2}$ gas is fed to the ablation probe via a high-pressure system; the gas then flows via throttle jets into an expansion chamber at the tip of the probe. Pressure loss during passage of the gas into the expansion chamber results in the cooling effect. Gas pressure in the high-pressure system was controlled with a pressure regulator (GMH 3155, Greisinger Elektronic, Regenstauf, Germany), and was maintained at a constant 600 psi. Energy was applicated via a high-frequency generator (VIO300 D, ERBE, Tübingen, Germany), with an operating frequency of $350 \mathrm{MHz}$, and maximum output of $300 \mathrm{~W}$.

\section{Ablation Parameters}

Three different ablation modes were employed ( $\bullet$ Fig. 2): continuous energy delivery (A); pulsed energy application with reduced ablation current during ablation pauses (B); and impedance-dependent energy delivery $(C)$. Continuous energy delivery used a constant current $\mathrm{I}_{\mathrm{c}}$ under continuous $\mathrm{CO}_{2}$ cooling. The tests were performed using various constant currents $\left(\mathrm{I}_{\mathrm{C}}=1000,1200,1400 \mathrm{~mA}\right)$.

During pulsed energy delivery (B), there was an ablation cycle with two intervals: one 90 second interval $\left(t_{H F}\right.$ high $)$ using high ablation current $\mathrm{I}_{\text {high }}=1500 \mathrm{~mA}$, followed by an interval $\left(\mathrm{t}_{\mathrm{HF} \text { low }}\right)$ with lower current $\mathrm{I}_{\text {low }}$. Cooling was active

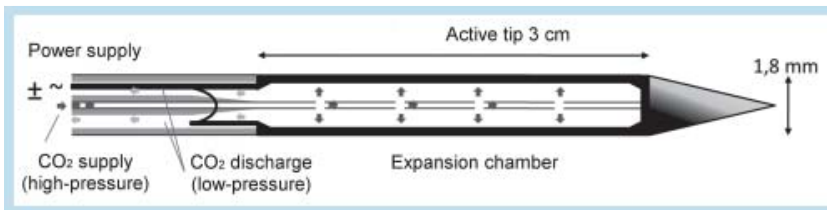

Fig. 1 Scheme of the cryo-RF applicator. Compressed CO2 from the high pressure system reaches the expansion chamber at the active tip of the RF applicator. Based on the Joule-Thomson-effect, the expansion of the pressurized gas cools the applicator.

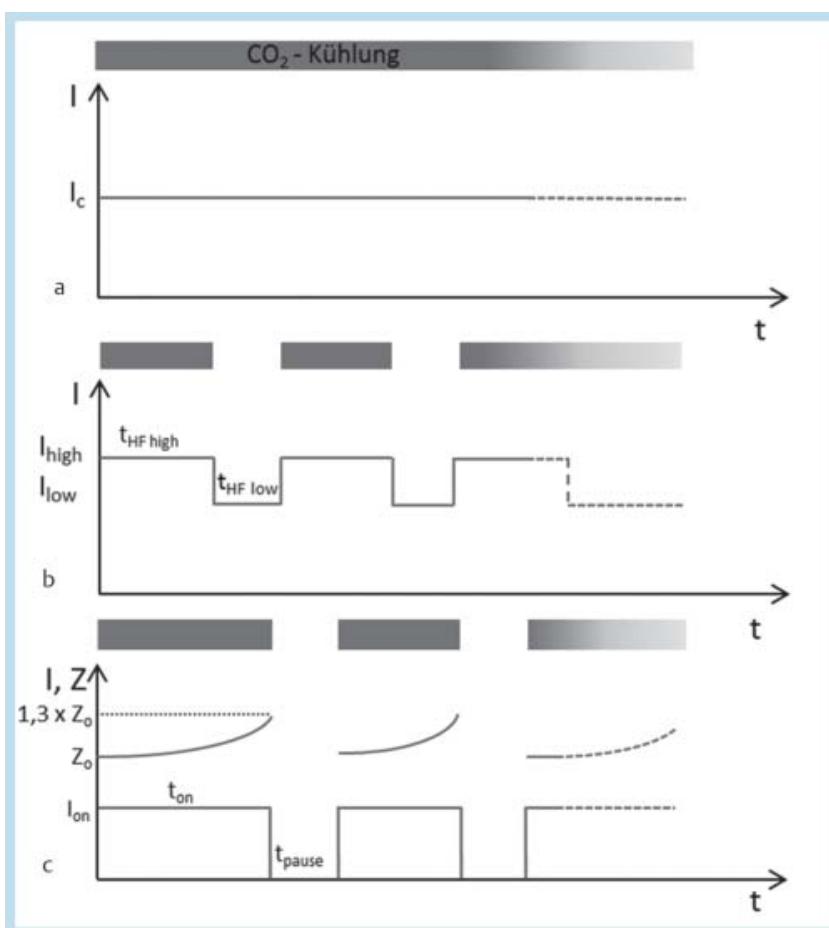

Fig. 2 Scheme of the three ablation modes: continuous energy delivery a, pulsed energy delivery with reduced current during ablation pause $\mathbf{b}$ and impedance-dependent energy delivery c. 
only during the $t_{\mathrm{HF} \text { high }}$ interval. In order to determine the optimum ablation parameters, the interval duration $t_{\mathrm{HF} \text { low }}$ and current $I_{\text {low }}$ were varied $\left(T_{H F}\right.$ low $=15,30,45 \mathrm{~min}$.; $\mathrm{I}_{\text {low }}=400,800,1200 \mathrm{~mA}$ ).

One cycle of impedance-dependent ablation (C) likewise consisted of two intervals. The first interval $\left(\mathrm{t}_{\mathrm{on}}\right)$ used $\mathrm{CO}_{2}$ cooling with an ablation current $\mathrm{I}_{\mathrm{on}}$ and impedance-dependent duration. During ablation, the parameters, including tissue impedance $Z$ were monitored and recorded (VioDocu, ERBE). When impedance increased by $30 \%$, energy delivery was interrupted. During the following pause interval $\left(t_{\text {pause }}\right.$, $\left.I_{\text {pause }}=0 \mathrm{~mA}\right) \mathrm{CO}_{2}$ cooling was stopped. The parameters $\mathrm{I}_{\mathrm{on}}$ und $t_{\text {pause }}$ were varied $\left(I_{\text {on }}=1200,1400,1600 \mathrm{~mA}\right.$; $t_{\text {pause }}=30$, $60,90 \mathrm{~s})$.

During all tests, the maximum ablation time was 20 minutes. The ablation cycles were repeated and the ablation continued until the maximum ablation time was reached, or until an irreversible increase in tissue impedance made additional ablation impossible.

\section{Experiments}

The ablation experiments were performed ex vivo on 12 fresh bovine livers provided by a local abattoir. At the time of testing, the tissue temperature lay between 21.5 and $23.0^{\circ} \mathrm{C}$. For each combination of parameters $n \geq 4$ ablation tests were performed, for a total of 108 tests. After each ablation the short axis (SA) and long axis (LA) diameters were measured with a vernier caliper; measurement was related to the white portion of the ablation zone [19] ( $\bullet$ Fig. 3). The ablation volume was calculated using the volume formula for ellipsoids $\left(\mathrm{V}=\pi / 6 \times\left(\mathrm{LA} \times \mathrm{SA}^{2}\right)\right)$ and the sphericity of the ablation zone was determined using the sphericity index $\mathrm{R}=\mathrm{SA} / \mathrm{LA}$. Ablation time in the event of early termination was documented. An ablation was repeated if the ablation reached the liver capsule or if it passed through a blood vessel.



Fig. 3 Coagulation zone after cryo-cooled RF ablation with impedancedependent energy delivery (Ion $=1400 \mathrm{~mA}$; tpause $=60 \mathrm{~s}$ ) with short axis and long axis diameter (SA, LA).

\section{Statistical Analysis}

For each ablation mode, the parameter combinations leading to the ablation zone with the greatest short axis diameter were determined. The result was investigated for significance using the analysis of variance (ANOVA). Employing ANOVA and the Tukey-Kramer HSD (Honestly Significant Difference) test, the three ablation modes were compared with respect to the ablation zones acquired using the most favorable combination of parameters. The average times of the three ablation modes were compared, and the influence of time upon the short axis diameter was investigated using the linear regression method. Statistical evaluation was performed using the JMP statistical software program (Version 9.0.0, SAS Institute Inc., Cary, USA). A p-value of $<0.05$ was considered statistically significant. Results were stated with standard deviation $( \pm$ SD).

\section{Results}

\section{$\nabla$}

Under continuous ablation (A) the greatest short axis diameter $(44.4 \mathrm{~mm} \pm \mathrm{SD} 4.1)$ was achieved with $\mathrm{I}_{\mathrm{c}}=1200 \mathrm{~mA}$. Using pulsed energy delivery (B), the ablation zone with the greatest short axis diameter $(46.1 \mathrm{~mm} \pm \mathrm{SD} 5.6)$ was achieved with $\mathrm{I}_{\mathrm{low}}=800 \mathrm{~mA}$ and $\mathrm{t}_{\mathrm{HF} \text { low }}=30 \mathrm{~s}$. Under impedance-controlled ablation $(C)$ the greatest short axis diameter $(51.1 \mathrm{~mm} \pm \mathrm{SD} 2.3)$ was generated with $t_{\text {pause }}=60 \mathrm{~s}$ and $\mathrm{I}_{\mathrm{on}}=1400 \mathrm{~mA}$. However, the ablation results with the optimum parameters do not differ statistically from the other ablation results within the groups (A), (B) and (C) $(p=0.40$ (A), $\mathrm{p}=0.53(\mathrm{~B}) ; \mathrm{p}=0.25(\mathrm{C})$ ).

Compared to the other ablation modes, impedance-controlled ablation (C) achieved zones with significantly greater short axis diameters (51.1 $\mathrm{mm} \pm \mathrm{SD} 2.3$; $\mathrm{p}=0.01)$. A statistically significant difference between continuous (A) and pulsed energy delivery (B) was not evident in this regard $(\mathrm{p}=0.75)(\bullet$ Fig. 4).

The maximum ablation time of 20 minutes was achieved using continuous energy delivery (A) in $16.7 \%$ of tests, $12.5 \%$ using pulsed energy output (B) and in $64.6 \%$ of tests using impedance-dependent energy delivery $(C)$. The significantly longest mean ablation time was reached using impedance-dependent delivery $(1061.6 \mathrm{~s} \pm \mathrm{SD} 42.4 \mathrm{p}=0.01)$. The mean ablation times using continuous energy delivery (715.3 s \pm SD 82.2) and pulsed delivery $(815.7 \mathrm{~s} \pm 41.3)$ did not differ significantly $(\mathrm{p}=0.93$ ). A moderately positive linear correlation with a correlation index of $\mathrm{R}=0.70$ and $\mathrm{R}=0.64$ was determined between the short axis diameter and ablation volume and the ablation time ( $\bullet$ Fig. 5).

The test results including diameter, volume and sphericity index are summarized in $\bullet$ Table 1.

\section{Discussion \\ $\nabla$}

Whereas the long axis of ablation zones can be affected by the length of the active applicator tip, the short axis represents the primary limitation to obtaining larger ablation zones. As the diameter of the ablation zone increases, the contact area to the surrounding tissue increases, resulting in increased energy loss during ablation which can only be offset with a higher application of energy. To make this pos- 

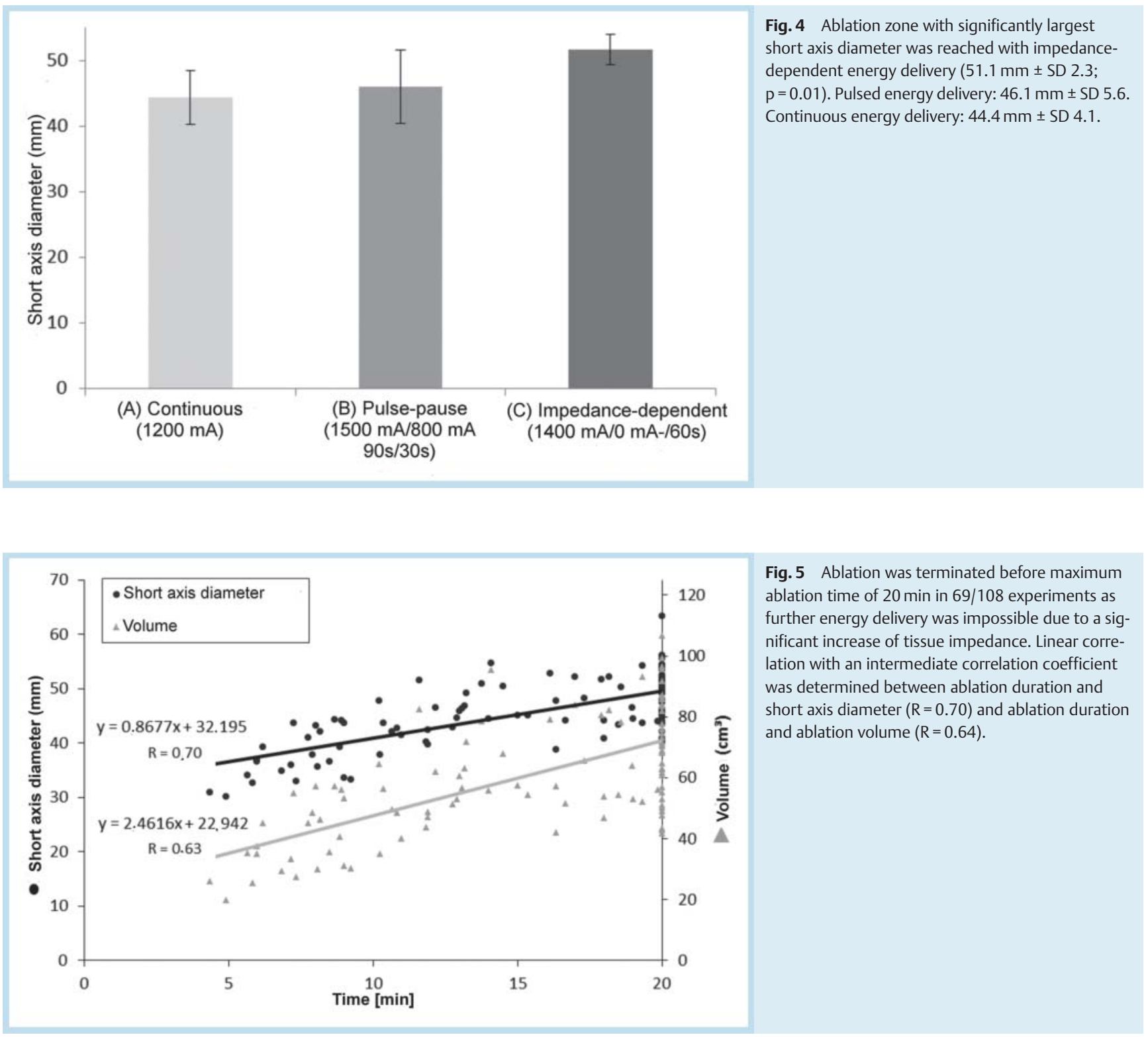

sible, the contact surface between the electrode and tissues can be increased, such as through the utilization of several or three-dimensional applicators, such as cluster electrodes $[12,20]$. Another approach involves improving the electrical conductivity of the tissue bordering on the electrode. A few studies showed that cooling the applicators results in enlargement of the ablation zone, since the tissue in contact with the electrode loses less fluid, thus delaying an increase in tissue impedance [14]. In addition, continuous application of lower outputs can hinder rapid drying of the zones while preventing an increase in impedance; however this does not result in an enlargement of the short axis diameter [21]. Due to the risk of incompletely ablated areas in the interior of the ablation zone, the combination of low output with intensive cooling should be considered as problematic [16]. Thus, most currently available RF ablation systems utilize sufficient cooling with the highest possible output energy [22]. Water cooling is the most common method used to reduce ablation probe temperature; it was shown, however, that more powerful gas-based systems provide greater energy delivery, thus allowing larger ablation zones $[15,16$, 23]. Although in those studies ablation was performed under continuous energy delivery, i.e. constant output, the goal of this investigation was to examine the effect of modified energy delivery on the ablation zone - particularly upon the short axis diameter. Although higher output resulting from gas cooling is considered determinative for larger ablation zones, this study shows that a brief interruption of energy input at least at the onset of the increase of impedance (ablation mode C) can increase the short axis of the ablation zone. This can be best explained by a limited effect of cooling on the boundary surface between the tissue and applicator, which diminishes with greater output and longer duration of ablation, even using gas cooling. Interruption of energy input clearly allows regeneration of the number of available charge carriers. This also explains why, when using impedance-controlled energy delivery, the longest significant ablations were acquired before the increase in impedance of the tissue bordering on the electrode resulted in termination of the ablation. In ablation 


\begin{tabular}{|c|c|c|c|c|c|}
\hline & & & & & \\
\hline$A$ & & & & & \\
\hline & $I_{c}$ & $1000 \mathrm{~mA}$ & $S A=39.2 \mathrm{~mm} \pm S D 5.7$ & & \\
\hline & & & $\mathrm{LA}=50.1 \mathrm{~mm} \pm \mathrm{SD} 5.4$ & & \\
\hline & & & $V=40.6 \mathrm{~cm}^{3} \pm S D 16.7$ & & \\
\hline & & & $R=0.79 \pm S D 0.19$ & & \\
\hline & & $1200 \mathrm{~mA}$ & $\mathrm{SA}=44.4 \mathrm{~mm} \pm \mathrm{SD} 4.1$ & & \\
\hline & & & $\mathrm{LA}=52.8 \mathrm{~mm} \pm \mathrm{SD} 1.9$ & & \\
\hline & & & $V=54.7 \mathrm{~cm}^{3} \pm S D 10.2$ & & \\
\hline & & & $R=0.84 \pm S D 0.08$ & & \\
\hline & & $1400 \mathrm{~mA}$ & $S A=41.4 \mathrm{~mm} \pm S D 5.6$ & & \\
\hline & & & $\mathrm{LA}=51.8 \mathrm{~mm} \pm \mathrm{SD} 2.3$ & & \\
\hline & & & $V=46.9 \mathrm{~cm}^{3} \pm S D 10.3$ & & \\
\hline & & & $R=0.80 \pm S D 0.06$ & & \\
\hline & & & $\mathrm{t}_{\mathrm{HFlow}}$ & & \\
\hline B & & & $15 s$ & $30 s$ & $45 s$ \\
\hline & $I_{\text {low }}$ & $400 \mathrm{~mA}$ & $\mathrm{SA}=42.8 \mathrm{~mm} \pm \mathrm{SD} 9.3$ & $S A=39.6 \mathrm{~mm} \pm S D 7.6$ & $S A=42.9 \mathrm{~mm} \pm S D 1.5$ \\
\hline & & & $\mathrm{LA}=51.1 \mathrm{~mm} \pm \mathrm{SD} 6.8$ & $\mathrm{LA}=51.4 \mathrm{~mm} \pm \mathrm{SD} 1.7$ & $\mathrm{LA}=50.9 \mathrm{~mm} \pm \mathrm{SD} 2.4$ \\
\hline & & & $V=52.6 \mathrm{~cm}^{3} \pm S D 25.6$ & $V=43.5 \mathrm{~cm}^{3} \pm S D 17.0$ & $V=49.0 \mathrm{~cm}^{3} \pm S D 4.5$ \\
\hline & & & $R=0.83 \pm S D 0.08$ & $R=0.77 \pm S D 0.14$ & $R=0.84 \pm S D 0.05$ \\
\hline & & $800 \mathrm{~mA}$ & $\mathrm{SA}=42.4 \mathrm{~mm} \pm \mathrm{SD} 4.0$ & $S A=46.1 \mathrm{~mm} \pm S D 5.6$ & $\mathrm{SA}=40.2 \mathrm{~mm} \pm \mathrm{SD} 4.2$ \\
\hline & & & $\mathrm{LA}=51.3 \mathrm{~mm} \pm \mathrm{SD} 1.1$ & $\mathrm{LA}=54.8 \mathrm{~mm} \pm \mathrm{SD} 4.1$ & $\mathrm{LA}=49.8 \mathrm{~mm} \pm \mathrm{SD} 4.6$ \\
\hline & & & $V=48.5 \mathrm{~cm}^{3} \pm S D 8.1$ & $V=62.4 \mathrm{~cm}^{3} \pm S D 18.2$ & $V=43.0 \mathrm{~cm}^{3} \pm S D 12.7$ \\
\hline & & & $R=0.83 \pm S D 0.09$ & $R=0.84 \pm S D 0.08$ & $R=0.81 \pm S D 0.02$ \\
\hline & & $1200 \mathrm{~mA}$ & $\mathrm{SA}=40.3 \mathrm{~mm} \pm \mathrm{SD} 7.7$ & $\mathrm{SA}=41.9 \mathrm{~mm} \pm \mathrm{SD} 7.0$ & $\mathrm{SA}=42.6 \mathrm{~mm} \pm \mathrm{SD} 6.4$ \\
\hline & & & $\mathrm{LA}=50.1 \mathrm{~mm} \pm \mathrm{SD} 5.1$ & $\mathrm{LA}=52.3 \mathrm{~mm} \pm \mathrm{SD} 1.1$ & $\mathrm{LA}=57.4 \mathrm{~mm} \pm \mathrm{SD} 6.5$ \\
\hline & & & $V=45.0 \mathrm{~cm}^{3} \pm S D 20.5$ & $\mathrm{~V}=48.9 \mathrm{~cm}^{3} \pm \mathrm{SD} 1.5$ & $V=55.7 \mathrm{~cm}^{3} \pm S D 18.3$ \\
\hline & & & $R=0.80 \pm S D 0.07$ & $R=0.80 \pm S D 0.14$ & $R=0.75 \pm S D 0.12$ \\
\hline & & & $t_{\text {pause }}$ & & \\
\hline C & & & $30 s$ & $60 s$ & $90 s$ \\
\hline & $\mathrm{I}_{\text {on }}$ & $1200 \mathrm{~mA}$ & $\mathrm{SA}=45.8 \mathrm{~mm} \pm \mathrm{SD} 4.5$ & $S A=46.1 \mathrm{~mm} \pm S D 4.5$ & $\mathrm{SA}=49.2 \mathrm{~mm} \pm \mathrm{SD} 3.1$ \\
\hline & & & $\mathrm{LA}=52.4 \mathrm{~mm} \pm \mathrm{SD} 4.2$ & $\mathrm{LA}=53.9 \mathrm{~mm} \pm \mathrm{SD} 3.6$ & $\mathrm{LA}=56.8 \mathrm{~mm} \pm \mathrm{SD} 5.1$ \\
\hline & & & $V=57.5 \mathrm{~cm}^{3} \pm S D 9.5$ & $V=60.2 \mathrm{~cm}^{3} \pm S D 14.9$ & $V=71.8 \mathrm{~cm}^{3} \pm S D 13.3$ \\
\hline & & & $R=0.88 \pm S D 0.13$ & $R=0.85 \pm S D 0.04$ & $R=0.87 \pm S D 0.07$ \\
\hline & & $1400 \mathrm{~mA}$ & $\mathrm{SA}=46.8 \mathrm{~mm} \pm \mathrm{SD} 6.6$ & $\mathrm{SA}=51.7 \mathrm{~mm} \pm \mathrm{SD} 2.3$ & $\mathrm{SA}=49.8 \mathrm{~mm} \pm \mathrm{SD} 6.2$ \\
\hline & & & $\mathrm{LA}=55.0 \mathrm{~mm} \pm \mathrm{SD} 4.9$ & $\mathrm{LA}=56.0 \mathrm{~mm} \pm \mathrm{SD} 3.1$ & $\mathrm{LA}=57.3 \mathrm{~mm} \pm \mathrm{SD} 2.2$ \\
\hline & & & $V=64.9 \mathrm{~cm}^{3} \pm S D 21.8$ & $V=78.3 \mathrm{~cm}^{3} \pm S D 8.1$ & $V=75.8 \mathrm{~cm}^{3} \pm S D 20.4$ \\
\hline & & & $R=0.85 \pm S D 0.08$ & $R=0.93 \pm S D 0.07$ & $R=0.87 \pm S D 0.10$ \\
\hline & & $1600 \mathrm{~mA}$ & $\mathrm{SA}=45.5 \mathrm{~mm} \pm \mathrm{SD} 4.0$ & $S A=50.6 \mathrm{~mm} \pm S D 7.6$ & $\mathrm{SA}=49.9 \mathrm{~mm} \pm \mathrm{SD} 0.1$ \\
\hline & & & $\mathrm{LA}=57.5 \mathrm{~mm} \pm \mathrm{SD} 2.0$ & $\mathrm{LA}=61.7 \mathrm{~mm} \pm \mathrm{SD} 5.4$ & $\mathrm{LA}=57.6 \mathrm{~mm} \pm \mathrm{SD} 5.6$ \\
\hline & & & $V=62.7 \mathrm{~cm}^{3} \pm S D 13.2$ & $V=85.0 \mathrm{~cm}^{3} \pm S D 27.3$ & $V=79.5 \mathrm{~cm}^{3} \pm S D 40.4$ \\
\hline & & & $R=0.70 \pm S D 0.05$ & $R=0.82 \pm S D 0.10$ & $R=0.86 \pm S D 0.12$ \\
\hline
\end{tabular}

Table 1 Summary of results.

$\mathrm{SA}=$ short axis diameter, $\mathrm{LA}=$ long axis diameter, $\mathrm{V}=$ volume, sphericity index $\mathrm{R}=\mathrm{SA} / \mathrm{LA}$.

mode $\mathrm{B}$, ablation was interrupted for a specific amount of time, and reduced ablation current maintained with cooling switched off. The basic idea behind reduced current during the pause in ablation is to reduce cooling off of the ablation zone during the pause. However, in the ex vivo model, this mode was not shown to be advantageous, since ablation results lay in the range of continuous ablation (mode A).

The primary limitation of our study was the performance of trials on an ex vivo bovine liver. Due to absent micro-and macro perfusion, the results cannot be unconditionally applied to in vivo ablation $[24,25]$. First, it should be anticipated that blood flow in larger vessels would lead to a diffusion of heat energy, and thus result in a change of the ablation zone shape. Second, it should be expected that micro-perfusion would delay drying out of the ablation zone, thus retarding an increase in impedance. Further, all ablations were performed at room temperature in order to achieve the most comparable test conditions. However, it should be assumed that deviations in tissue temperature would likewise influence the results of ablation.

In summary, this ex vivo study was able to demonstrate that by using cryo-cooled RF applicators, zones with the greatest short axis diameters could be created if the ablation is briefly interrupted as soon as there is an increase in tissue impedance. In addition, when cryo-cooled RF applicators are employed using impedance-controlled energy delivery, ablation interruption due to loss of tissue conductivity occurs later than when continuous energy delivery is applied. A positive effect of reduced cutoff current during pauses in ablation could not be supported. 


\section{Clinical Relevance of the Study}

- Impedance-dependent energy delivery during RF ablation using cryo probes prevents premature termination due to loss of tissue conductivity.

- Impedance-dependent energy delivery is superior to continuous energy output with respect to the size of the ablation zone.

- Reduced current during pauses in ablation does not have a positive effect on the size of the ablation zone.

\section{References}

1 Lencioni R, Cioni D, Crocetti L et al. Early-stage hepatocellular carcinoma in patients with cirrhosis: long-term results of percutaneous image-guided radiofrequency ablation. Radiology 2005; 234: 961 - 967

2 Bale R, Widmann G, Schullian $P$ et al. Percutaneous stereotactic radiofrequency ablation of colorectal liver metastases. Eur Radiol 2012; 22: 930-937

3 Chen MS, Li JQ Zheng Y et al. A prospective randomized trial comparing percutaneous local ablative therapy and partial hepatectomy for small hepatocellular carcinoma. Ann Surg 2006; 243: 321-328

4 Gillams A, Khan Z, Osborn P et al. Survival after radiofrequency ablation in 122 patients with inoperable colorectal lung metastases. Cardiovasc Intervent Radiol 2013; 36: 724-730

5 Mahnken AH, Gunther RW, Tacke J. Radiofrequency ablation of renal tumors. Eur Radiol 2004; 14: 1449-1455

6 Gebauer B, Collettini F, Bruger C et al. Radiofrequency ablation of osteoid osteomas: analgesia and patient satisfaction in long-term follow-up. Fortschr Röntgenstr 2013; 184: 959-966

7 Solbiati L, Livraghi T, Goldberg SN et al. Percutaneous radio-frequency ablation of hepatic metastases from colorectal cancer: long-term results in 117 patients. Radiology 2001; 221: 159-166

8 Berber E, Tsinberg $M$, Tellioglu $G$ et al. Resection versus laparoscopic radiofrequency thermal ablation of solitary colorectal liver metastasis. J Gastrointest Surg 2008; 12: 1967 - 1972

9 Gillams AR, Lees WR. Five-year survival in 309 patients with colorectal liver metastases treated with radiofrequency ablation. Eur Radiol 2009; 19: 1206 - 1213

10 Lencioni RA, Allgaier HP, Cioni D et al. Small hepatocellular carcinoma in cirrhosis: randomized comparison of radio-frequency thermal ablation versus percutaneous ethanol injection. Radiology 2003; 228: $235-240$
11 Goldberg SN, Gazelle GS, Dawson SL et al. Tissue ablation with radiofrequency using multiprobe arrays. Acad Radiol 1995; 2: 670-674

12 Goldberg SN, Solbiati L, Hahn PF et al. Large-volume tissue ablation with radio frequency by using a clustered, internally cooled electrode technique: laboratory and clinical experience in liver metastases. Radiology 1998; 209: $371-379$

13 Lorentzen T. The loop electrode: in vitro evaluation of a device for ultrasound-guided interstitial tissue ablation using radiofrequency electrosurgery. Acad Radiol 1996; 3: 219-224

14 de Baere T, Denys A, Wood BJ et al. Radiofrequency liver ablation: experimental comparative study of water-cooled versus expandable systems. Am J Roentgenol American journal of roentgenology 2001; 176: $187-192$

15 Rempp H, Voigtlander M, Clasen S et al. Increased ablation zones using a cryo-based internally cooled bipolar RF applicator in ex vivo bovine liver. Invest Radiol 2009; 44: 763 - 768

16 Rempp H, Scharpf $M$, Voigtlaender $M$ et al. Sustained growth of the ex vivo ablation zones' critical short axis using gas-cooled radiofrequency applicators. Cardiovasc Intervent Radiol 2011; 34: 149-155

17 Schmidt D, Trubenbach J, Konig CW et al. Radiofrequency ablation ex vivo: comparison of the efficacy of impedance control mode versus manual control mode by using an internally cooled clustered electrode. Fortschr Röntgenstr 2003; 175: 967-972

18 Goldberg SN, Stein MC, Gazelle GS et al. Percutaneous radiofrequency tissue ablation: optimization of pulsed-radiofrequency technique to increase coagulation necrosis. J Vasc Interv Radiol 1999; 10: 907-916

19 Goldberg SN, Grassi CJ, Cardella JF et al. Image-guided tumor ablation: standardization of terminology and reporting criteria. Radiology 2005; 235: $728-739$

20 Bruners P, Schmitz-Rode T, Gunther RW et al. Multipolar hepatic radiofrequency ablation using up to six applicators: preliminary results. Fortschr Röntgenstr 2008; 180: 216-222

21 Clasen S, Geng A, Herberts $T$ et al. Internally cooled bipolar radiofrequency ablation: is a lower power output more effective? Fortschr Röntgenstr 2007; 179: 282-288

22 Wiggermann P, Jung EM, Stroszczynski C. Radiofrequency ablation - is a technique finished? Radiologe 2012; 52: 9-14

23 Rempp $H$, Voigtlander $M$, Schenk $M$ et al. Internally gas-cooled radiofrequency applicators as an alternative to conventional radiofrequency and microwave ablation devices: an in vivo comparison. Europ J Radiol 2013; 82: 350-355

24 Bitsch RG, Dux M, Helmberger T et al. Effects of vascular perfusion on coagulation size in radiofrequency ablation of ex vivo perfused bovine livers. Invest Radiol 2006; 41: 422 - 427

25 Frericks BB, Ritz JP, Albrecht T et al. Influence of intrahepatic vessels on volume and shape of percutaneous thermal ablation zones: in vivo evaluation in a porcine model. Invest Radiol 2008; 43: 211-218 